\title{
Review Article \\ Establishing Natural Nootropics: Recent Molecular Enhancement Influenced by Natural Nootropic
}

\author{
Noor Azuin Suliman, ${ }^{1}$ Che Norma Mat Taib, ${ }^{1}$ Mohamad Aris Mohd Moklas, ${ }^{1}$ \\ Mohd Ilham Adenan, ${ }^{2}$ Mohamad Taufik Hidayat Baharuldin, ${ }^{1}$ and Rusliza Basir ${ }^{1}$ \\ ${ }^{1}$ Department of Human Anatomy, Faculty of Medicine and Health Sciences, Universiti Putra Malaysia, 43400 Serdang, Malaysia \\ ${ }^{2}$ Atta-ur-Rahman Institute for Natural Product Discovery, Aras 9 Bangunan FF3, UiTM Puncak Alam, \\ Bandar Baru Puncak Alam, 42300 Selangor Darul Ehsan, Malaysia \\ Correspondence should be addressed to Che Norma Mat Taib; chenorma@upm.edu.my
}

Received 31 May 2016; Accepted 18 July 2016

Academic Editor: Manel Santafe

Copyright (C) 2016 Noor Azuin Suliman et al. This is an open access article distributed under the Creative Commons Attribution License, which permits unrestricted use, distribution, and reproduction in any medium, provided the original work is properly cited.

Nootropics or smart drugs are well-known compounds or supplements that enhance the cognitive performance. They work by increasing the mental function such as memory, creativity, motivation, and attention. Recent researches were focused on establishing a new potential nootropic derived from synthetic and natural products. The influence of nootropic in the brain has been studied widely. The nootropic affects the brain performances through number of mechanisms or pathways, for example, dopaminergic pathway. Previous researches have reported the influence of nootropics on treating memory disorders, such as Alzheimer's, Parkinson's, and Huntington's diseases. Those disorders are observed to impair the same pathways of the nootropics. Thus, recent established nootropics are designed sensitively and effectively towards the pathways. Natural nootropics such as Ginkgo biloba have been widely studied to support the beneficial effects of the compounds. Present review is concentrated on the main pathways, namely, dopaminergic and cholinergic system, and the involvement of amyloid precursor protein and secondary messenger in improving the cognitive performance.

\section{Introduction}

The "nootropic" or simplified as a "smart drug," "brain booster," or "memory enhancing drug," is a common term that will tag along with the compound responsible for the enhancement of mental performance. By definition, nootropic is a compound that increases mental functions including memory, motivation, concentration, and attention [1]. There are two different nootropics: synthetic, a lab created compound such as Piracetam, and notable natural and herbal nootropics, such as Ginkgo biloba and Panax quinquefolius (American Ginseng).

Natural nootropics are proven in boosting the brain function while at the same time making the brain healthier. Nootropics act as a vasodilator against the small arteries and veins in the brain [2]. Introduction of natural nootropics in the system will increase the blood circulation to the brain and at the same time provide the important nutrient and increase energy and oxygen flow to the brain [3]. Despite the 3\% weight of total body weight, the brain receives around $15 \%$ of the body's total blood supply and oxygen. In fact, the brain can only generate energy from burning the glucose [4], proving that neuron depends on the continuous supply of oxygen and nutrients.

In contrast to most of other cells in the body, neuron cannot be reproduced and is irreplaceable. The neuron cells are persistently expending the converted energy to maintain the repair of the cell compartments. The energy generated from the glucose is crucial for maintenance, electrical, and neurotransmitter purposes [5]. The effect of natural nootropics is also shown to reduce the inflammation occurrence in the brain [6]. The administration of nootropics will protect the brain from toxins and minimising the effects of brain aging. Effects of natural nootropics in improving the brain function 
are also contributed through the stimulation of the new neuron cell. As incentive from the new neuronal cell, the activity of the brain is increased, enhancing the thinking and memory abilities, thus increasing neuroplasticity [7].

Commercialised natural nootropics in the market are reacting at different mechanisms, thus affecting different parameters. Natural nootropics alter the concentration of existing neurotransmitters. Natural nootropics have been disclosed to stimulate the release of dopamine, uptake of choline, cholinergic transmission, function of $\alpha$-amino-3-hydroxy-5methyl-4-isoxazole propionate (AMPA) receptor, turnover of phosphatidylinositol, and activity of phosphatase A2 [8]. Some of the natural nootropics act as a positive allosteric modulator for acetylcholine or glutamate receptor [9]. The release of neurotransmitter [10] and the increase activity of neurotransmitter [11] induced by natural nootropics facilitate the long-term potential (LTP) and improve synaptic transmission.

\section{Suggested Molecular and Cellular Mechanisms}

Establishment of new natural nootropic must consider the cellular and molecular mechanism of cognitive processes. A neuron has a known structural and functional plasticity or termed as synaptic plasticity, responsible for synaptic remodelling or known as cellular learning. Modulation in the molecular level in the neuron will alter the cognitive properties [12]. Through this review, there are few suggested mechanisms mediating the effects of nootropics in cognitive performance.

2.1. Glutaminergic Signalling. Glutamatergic transmission is an example of synaptic plasticity associated with LTP. Glutamate is an essential neurotransmitter involved in cognitive processes [13]. There are two different types of glutamate receptors: ionotropic (AMPA, kainite and NMDA receptors) and metabotropic receptors, distributed on the pre- and postsynaptic sites of the neuron. These receptors are responsible for neuronal network that allows the cognitive performance [14]. The release of glutamate will activate N-methyl-Daspartate (NMDA) and AMPA receptors. AMPA receptor is responsible for synaptic transmission, while NMDA receptor is responsible for classic learning and memory [15]. The brain will respond by opening the $\mathrm{Na}^{+} / \mathrm{K}^{+}$ion channel and depolarising the cell membrane [16]. However, hyperactivity of glutamate receptors can cause oxidative stress to occur responding to the cognitive dysfunction [17].

Glutamate, which acts by activating NMDA receptor, is a main excitatory neurotransmitter related in cognition function [15]. The NMDA receptor is an ionotropic channel and distributes abundantly in the hippocampus, cortex, and thalamus [18] that assists the movement of $\mathrm{Ca}^{2+}, \mathrm{Na}^{+}$, and $\mathrm{K}^{+}$ions [19]. Activation of the NMDA receptor is reported to initiate the LTP observed in the hippocampus. LTP is part of the synaptic plasticity responsible for the physiological changes of cognitive functions [20]. LTP is remarkably studied in the hippocampus associated with learning and memory [21]. The increased $\mathrm{Ca}^{2+}$ permeability and blockage of voltage-dependent $\mathrm{Mg}^{2+}$ contribute to the synaptic plasticity and the formation of memory [19]. Increased $\mathrm{Ca}^{2+}$ also affects the gene and protein expression for LTP and, subsequently, may lead to neurotoxicity due to overexcitation of glutamate observed in Alzheimer's disease [16]. Blockage of NMDA receptor displays the cognitive impairment in animal models. The models are mimicking the association between the receptor to dementia [22] and schizophrenia [23] diseases. Downregulated glutamate is observed in Alzheimer's disease [24] accompanied by the reduction of NMDA receptor in the hippocampus [25].

AMPA receptor, another type of ionotropic channel, is known to mediate the fast and immediate postsynaptic response to glutamate release and thus may contribute to synaptic plasticity [26]. The receptor can be found throughout the brain, especially in the thalamus, hypothalamus, cerebral cortex, hippocampus, basal ganglia, and cerebellum [18], being also permeable for $\mathrm{Na}^{+}$and $\mathrm{K}^{+}$[27]. Increased density of AMPA receptor in the hippocampus was shown to enhance the memory consolidation [28]. The use of AMPA modulator causes the deactivation and desensitisation of the receptor in the hippocampus thus subsequently facilitating the cognitive performances, including short-term memory [29].

2.2. Cholinergic System. In regulating the cognitive functions, the central cholinergic system is suggested to be an essential neurotransmitter associated with, namely, acetylcholine (ACh) [30]. The neuronal nicotinic ACh receptor is established located on the presynaptic terminal and applies an action on hippocampal synaptic transmission via stimulating the release of glutamate [31]. The activation of nicotinic ACh receptor is stimulated by activation of protein kinase $\mathrm{C}$ (PKC). These events subsequently maintain the phosphorylation of the receptor [32] and sustain the upregulation of glutamate release. Afterward, the high expression of glutamate initiates the long-lasting acceleration of hippocampal synaptic transmission [33]. Taking piracetam as an example, nootropics are suggested to involve the biochemical modifications in the aged brain [34]. Treatment of nootropics shows pronounced effects in the impaired brain functions induced by number of noxious stimuli, for example, hypoxia, aging, and injury [35].

Cognitive dysfunction is related to diminish cholinergic function, treated by stimulation of central cholinergic activity expressing the improvement of cognitive performances [36]. The loss of neuronal cholinergic observed in the hippocampal area is responsible for the major characteristic of Alzheimer's disease. In treating Alzheimer's disease-type senile dementia, central cholinergic system is suggested to be improved. Administration of established nootropics is established to increase the level of ACh and upregulation of receptor binding for cholinergic in the frontal cortex and hippocampus [37]. Downregulation of noradrenergic function is studied to diminish the behavioural impairment due to degeneration of cholinergic system [38]. The nootropics activities are observed through the downregulated ACh esterase activity. The reduction subsequently leads to upregulation of ACh expression in the brain. Thus, good agents of nootropics 
are able to decrease norepinephrine (NE) and elevate the 5hydroxytryptamine (5-HT) expression observed in the central cortex, hippocampus, and hypothalamus [39].

2.3. Amyloid Precursor Protein. Dysfunction of the cholinergic system in Alzheimer's disease is also accompanied by the involvement of amyloid protein, specifically amyloid $\beta$-protein, and neurofibrillary tangles [40]. Modulation of processing of cellular component is also influenced by the neuronal transmission and synaptic plasticity. Amyloid precursor protein (APP) is one example of cellular component affected. APP is detected in the membrane of synaptic preparation and leading to the involvement of a fragment of APP in synaptic formation and maintenance [41]. The consequences of the influence of APP seem to contribute to the memory formation [42]. Introduction of natural nootropics increases the learning and memory performance, which causes upregulation of APP expression [43]. Knockout APP in mice was observed to impair the behavioural activity and alter the structure and length of the neuron [44]. In introducing natural nootropic, modulation of APP processing must be approached since it mediates the formation of specific neurotropic APP fragments, which is important for memory functions.

Patients diagnosed with Alzheimer's disease are expressed with the deposition of insoluble or oxidised amyloid- $\beta$ derived from APP present in the brain [45]. $\beta$-amyloid peptide is another fragment derived from the APP, contributing to the impairment of short-term working memory [46]. Oversynthesis of $\beta$-amyloid from APP may be influenced by the increased neuronal activity thus subsequently causing the depression of synaptic transmission [47]. The patient's brain also contains an activated caspase-3. Caspase- 3 is a cysteine protease that facilitates the apoptosis induced by the mitochondrion [48]. Marx [49] has listed a possible reason of the onset of Alzheimer's disease, namely, due to deposition of amyloid- $\beta$, apoptosis, and presence of oxidative stress. The amyloid- $\beta$-induced apoptosis leads to the neuronal degeneration [50]. High expression of amyloid- $\beta$ in the neuron stimulates neuronal apoptosis death due to induction of caspase- 3 activities [51]. Production of amyloid- $\beta$ fibril is an indicator for development of Alzheimer's disease. The amyloid- $\beta$ fibril is responsible for permeability of lipid membrane [52] and stimulation of $\mathrm{Ca}^{2+}$ conductance [53].

2.4. Secondary Messenger. Schwartz [54] has claimed the involvement of secondary messenger implicated in the cognitive purpose. The evolution of the intracellular signalling cascade involves various enzymes and selective protein-protein interactions in response to the cognitive performance. LTP, as mentioned before, is related to the activation of NMDA receptor and leads to influx of $\mathrm{Ca}^{2+}$. It is originating the series of events causing the activation of pre- and postsynaptic mechanisms [55]. $\mathrm{Ca}^{2+}$ is observed to activate $\mathrm{PKC}$ in the dentate gyrus [56], a molecule that is involved in learning and memory processes [57]. The administration of PKC activator [58] and nootropic drugs were observed to improve the memory performances, suggesting the involvement of similar pathway, the PKC pathway [59].
Upon PKC activation, it localises to specific subcellular sites and confers different physiological function [60]. The failure for this translocation to occur is found in normal ageing and number of neuronal pathologies [61]. Considering the role of $\mathrm{PKC}$ in learning and memory mechanisms, PKC improves synaptic plasticity in the brain. In addition, diminished calcium/calmodulin-dependent protein kinase II (CaMKII) and PKC activity contribute to downregulation of NMDA receptor, thus reducing the release of glutamate [62].

2.5. Miscellaneous. Insulin receptor becomes another target for investigating the effect of nootropic in cognitive purposes. Insulin plays a role in the neuropathological views, including involvement in neurotropic and neuromodulatory functions [63]. In the central nervous system (CNS), insulin is synthesised and released from neuron as a response to depolarisation [64]. As observed from a number of studies, insulin receptors are also responsible for learning and memory [65]. High expression of insulin receptors is found in the hippocampus, including in the dentate gyrus and CA1 pyramidal cells [66]. Neuron insulin or insulin receptor in the hippocampus can modulate the synaptic activity mediated by NMDA, which subsequently suppress the AMPA and $\mathrm{GABA}_{\mathrm{A}}$ receptors. It alters the synthesis and the activity of a number of neurotransmitters [67]. Activation of neuronal insulin will stimulate the signalling pathway of cognitive function, including activation of mitogen-activated protein kinase (MAPK), PKC, and phosphatidylinositol-3-kinase (PI3K) [67]. Diabetic rats were observed to experience cognitive impairment and LTP [68].

Other than insulin receptor, angiotensin receptor also facilitates the signal transduction in the CNS. Angiotensin, a peptide hormone, is part of the renin-angiotensin system that stimulates the release of aldosterone from the adrenal cortex. Angiotensin II (Ang II), one of the subtypes of angiotensin, regulates the blood pressure via a number of actions. The most significant actions are vasoconstriction, renal actions, and increased aldosterone biosynthesis [69]. Ang II also interacts with other neurotransmitters, causing the release of noradrenaline and the synthesis of serotonin [70]. Ang II facilitates the cognitive and behavioural processes through its specific receptors and metabolites expressed in animal models [71]. Upon cognitive impairment of Alzheimer's disease patient, the Ang II in the brain inhibits the release of acetylcholine through inhibition on angiotensin type 1 receptor (AT1) [72]. Acetylcholine is known as a critical neurotransmitter responsible for memory.

Review by van der Staay et al. [73] has established a definition of cognition enhancer. Overall, a cognition enhancer is a pharmacological compound that enhances the mnemonic and cognitive function that can cross the blood-brain barrier. The cognition function is influenced by the cognition enhancer including the learning, consolidation and retrieval, and memory. As a contrast, it does not have psychopharmacological activity such as sedation and has minimal or no adverse effects with low toxicity level. Listed below are examples of natural nootropic that were proved to improve cognitive and memory properties. 


\section{Examples of Nootropic}

3.1. Pyrrolidinone Derivatives. Pyrrolidinone is a class of 5-membered lactams with a four-carbon heterocyclic ring structure with biological interest [74] found in many pharmaceuticals and natural products. The synthesis of nootropic from pyrrolidinone derivatives has common features including enhancing the learning process, diminishing the impaired cognition, and protecting against brain damage. Number of pyrrolidine derivatives are commercially available, including piracetam, oxiracetam, aniracetam, and promiracetam [75]. Administration of aniracetam or piracetam affects the muscarinic receptor binding in the different brain regions [76]. Study by Pilch and Müller [77] had established the upregulation of $\mathrm{m}$-cholinoceptor in the brain responding to the aging brain.

Piracetam or 2-oxo-1-pyrrolidineacetamide, a cyclic derivative of gamma-aminobutyric acid (GABA) [78], is widely used in treating senile dementia and Alzheimer's disease [79]. Studies showed the role of piracetam in enhancing the memory and learning [80] and act synergistically with choline leading to greater enhancement of cognition. Winnicka et al's study [78] showed the effect of piracetam on regulating the release of glutamate observed in the cortex and hippocampus, suggesting involvement of NMDA receptor induced by piracetam. Despite having a low affinity for glutamate receptors, piracetam initiates a number of effects on the receptors, for example, on AMPA receptor. Treatment of piracetam causes activation of AMPA receptor thus stimulating the influx of $\mathrm{Ca}^{2+}$ in the brain and increasing the density of AMPA receptors in the synaptic membrane of the cortex. Piracetam also causes the release of glutamate stimulated by potassium in the hippocampal nerves [81]. Recent reports suggest the neuroenhancing effect of piracetam is via stimulation of acetylcholinergic and glutamatergic systems, plus elevation of membrane permeability [82].

Introduction of aniracetam is usually related to the involvement of AMPA receptor [83], cholinergic system [84], and metabotropic receptor [85], as part of cognition function. Aniracetam, including pyrrolidinone derivative compounds, is established to diminish the cognitive impairment [86]. Systemic administration of aniracetam improves the cognitive performance observed behaviours, suggesting the involvement of AMPA in the dentate gyrus [87]. The effects of cognitive enhancer of aniracetam are postulated due to the slow rate of deactivation [88] and desensitisation of AMPA receptors [89] observed using hippocampal slide. Other studies had suggested the involvement of activated hippocampal $\mathrm{PKC}$ and sustained ratio of membrane and cytosolic PKC $\gamma$ [90]. The enhancement of PKC $\gamma$ is subsequently induced by the phosphorylation of glutamate receptor subunits, thus modifying the channel kinetics of AMPA receptor [91]. The study showed that the intrahippocampal aniracetam mediates the formation of behavioural LTP, thus representing the synaptic mechanism induced by the treatment [83].

Another example of pyrrolidinone derivative is nefiracetam (N-(2,6-dimethyl-phenyl)-2(2-oxo-1-pyrrolidinyl)), a piracetam-like nootropic agent. Studies show that the compound improves the impaired cognitive due to drugs [92], morphine [93], or ageing [94]. Intake of nefiracetam is postulating the cholinergic system, as ACh receptor enhances the release of neurotransmitter [31]. Nefiracetam is studied to influence the phosphorylation of nicotinic ACh receptor by activating the PKC, thus helping the release of neurotransmitter from the presynaptic terminal [32]. Synaptic transmission influenced by nefiracetam is not mediated through the blocking of GABAergic transmission and enhanced postsynaptic ionotropic glutamate receptor. Interestingly, nefiracetam is improving the synaptic strength by aiming at the nicotinic ACh receptor [33] possibly by $\mathrm{Na}^{+}$without affecting the permeability of $\mathrm{Ca}^{2+}$ [32]. Another study suggests that the inhibition of PKA is responsible for the effect of nefiracetam on $\mathrm{Ca}^{2+}$ channel [32]. In contrast to piracetam and oxiracetam, nefiracetam enhances the $\mathrm{N}$ - and L-type $\mathrm{Ca}^{2+}$ channels but not T-type [95].

DM235 or sunifiram is a recent compound structurally related to piracetam and is known to prevent cognitive deficits. The compound is observed to improve the impaired cognitive functions by inhibiting the induction of amnesia [96]. As discussed previously, pyrrolidinone derivatives prevent the amnesia induced by the impaired cholinergic system [97] and ameliorate the cognitive deficits [98]. Similar to other pyrrolidinone derivatives, sunifiram increases the release of neurotransmitter from the presynaptic terminal [99]. Amnesia can be induced by altering the neurotransmitter system through GABA. Activation of GABA receptor impairs the cognitive function including the learning and memory processes [100]. In contrast to other pyrrolidinone derivatives, sunifiram is more potent while having a similar characteristics with piracetam. Sunifiram is observed to ameliorate the memory function and has less adverse effects [81]. A recent study reports the improvement of hippocampal LTP induced by sunifiram is mediated by the glycine-binding site of NMDA receptor [101], an attractive binding site for Alzheimer's disease drugs [102]. Thus, the reaction of sunifiram on the same binding site is suggested to ameliorate the impaired cognitive function of Alzheimer's disease patients [101]. Stimulation of the binding is also associated with the increased autophosphorylated CaMKII and PKC $\alpha$ thus suggesting the enhanced memory and hippocampal LTP [103].

3.2. Bacopa monnieri. Bacopa monnieri or Brahmi is derived from the family of Scrophulariaceae, found throughout the Indian subcontinent in a wet, damp, and marshy area [104]. It has purple flowers with numerous branches and small oblong leaves (Figure 1). This plant is known to be used for number of nervous system disorders, including insomnia, anxiety, and epilepsy. According to Ayurvedic medical practitioners, Bacopa monnieri is categorised as a medhya rasayana, a compound that stimulates and enhances the memory and intellect. These properties were studied preclinically and clinically [105]. The property of memory, facilitating action of this plant, is contributed by the chemical constituents of bacoside $\mathrm{A}$, assigned as 3-(a-L-arabinopyranosyl)-O- $\beta$-Dglucopyranoside-10, 20-dihydroxy-16-keto-dammar-24-ene [106], and bacoside B [107]. The treatment of a mixture of 


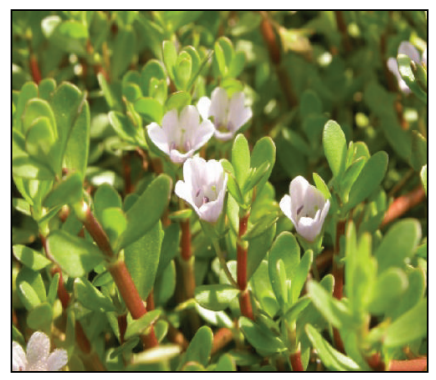

(a)

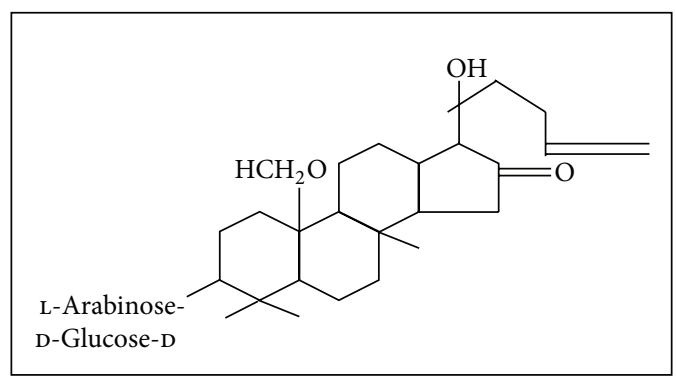

(b)

FIGURE 1: Bacopa monnieri. The plant has purple flowers with oblong leaves found throughout the Indian subcontinent. This plant is classified under the family of Scrophulariaceae. On the right is the chemical structure for bacosides [107].

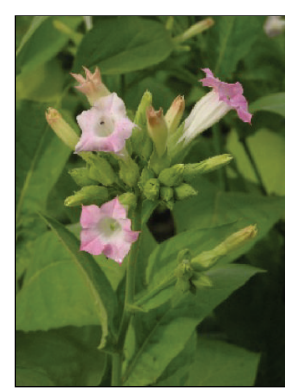

(a)

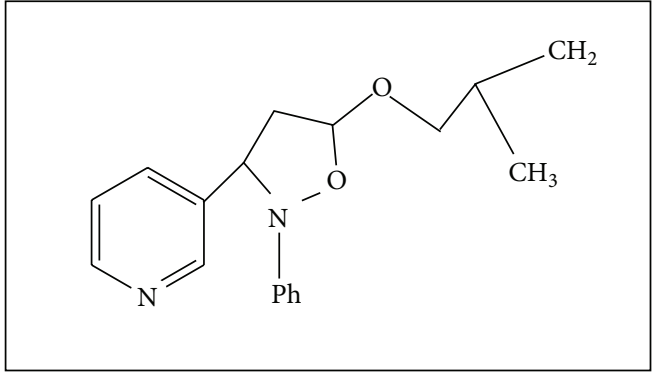

(b)

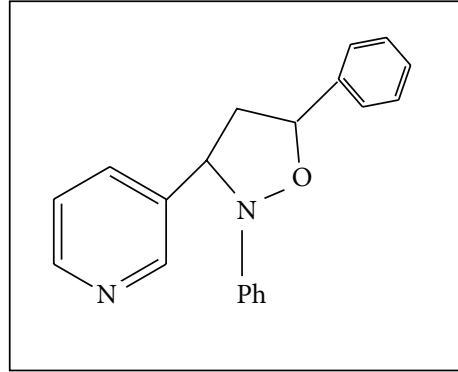

(c)

Figure 2: Nicotiana mutabilis. The plant is classified under the family of Solanaceae and contains nicotine as psychoactive compound (a). Compound A, syn-5-isobutoxy-2-phenyl-3-(3-pyridyl)-isoxazolidine (b), and compound B, syn-2,5-diphenyl-3-(3-pyridyl)-isoxazolidine (c), are example of synthesised nootropics derived from nicotine for learning and memory purposes [122].

bacosides $\mathrm{A}$ and $\mathrm{B}$ is mediating the three types of learning function, procedural, declarative, and spontaneous, and improves the episodic memory observed in animal models [108]. Beside enhancing cognition and memory functions, Bacopa monnieri are also known for their anxiolytic effects and in managing the convulsive sicknesses [109].

Singh and colleagues [110] had suggested the membrane dephosphorylation triggered by bacosides concurrently leads to elevation in protein and RNA turnover observed in certain brain regions. The nootropics effect of Bacopa monnieri is mediated by enhancement of protein kinase activity and production of protein in the hippocampus [39]. Study done by Anand and colleagues [111] demonstrated the characteristics of natural antioxidant and DNA damage preventing agent of the Bacopa monnieri. Other effects of Bacopa monnieri are including hepatoprotective agent against morphine toxicity [112], calcium antagonist [113], anticancer agent [114], and antiaddictive agent [115]. Despite that, the combination of bacosides $\mathrm{A}$ and $\mathrm{B}$ also was studied to express antistress property [116], protecting the brain from smoking induced membrane damage [117], and protective function against Dgalactosamine induced liver injury [118].

3.3. Nicotine. Nicotine is a potent parasympathomimetic alkaloid derived from the family of plants of Solanaceae (Figure 2). The psychoactive nicotine is found in the leaves of Nicotiana rustica, the tobacco plant Nicotiana tabacum,
Duboisia hopwoodii, and Asclepias syriaca [119]. Despite its addiction liability and undesired adverse effects [120], nicotine is found to improve learning and memory properties and enhance the memory impairment due to lesion of the septohippocampal pathways or aging. Downregulated expression of nicotinic receptor is observed in Alzheimer's disease patients [121].

Due to the prohibition of the use of nicotine, novel nicotine analogue is synthesised and evaluated, namely, syn-5-isobutoxy-2-phenyl-3-(3-pyridyl)-isoxazolidine (compound A) and syn-2,5-diphenyl-3-(3-pyridyl)-isoxazolidine (compound B) [122]. Nicotine and its synthesised analogs are established to react on different pathways, expressing improvement in memory [123]. Compounds A and B are postulated to stimulate the release of acetylcholine through the activation of presynaptic nicotine acetylcholine receptors. These receptors are responsible for modulating the release of neurotransmitter [124].

3.4. Ginkgo biloba. Ginkgo biloba or maidenhair tree is the only species derived from family of Ginkgophyta and the order of Ginkgoales. It is called a "living fossil" since the morphology and features of the plant are changed for over 100 million years [125]. The plant is well-known for its medical used as well as being a source of food [126]. Despite the lack of reports, Ginkgo biloba is claimed to have neuroprotective effects observed in human and animal models [127]. A recent 


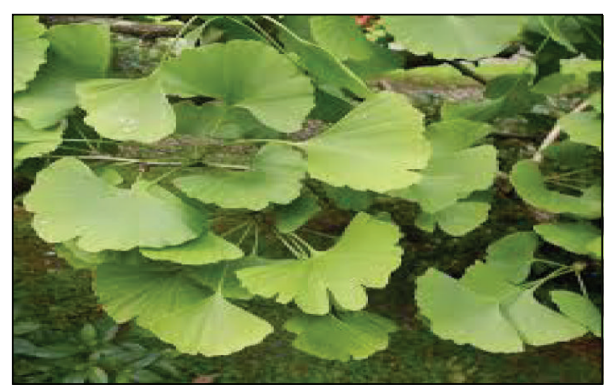

(a)

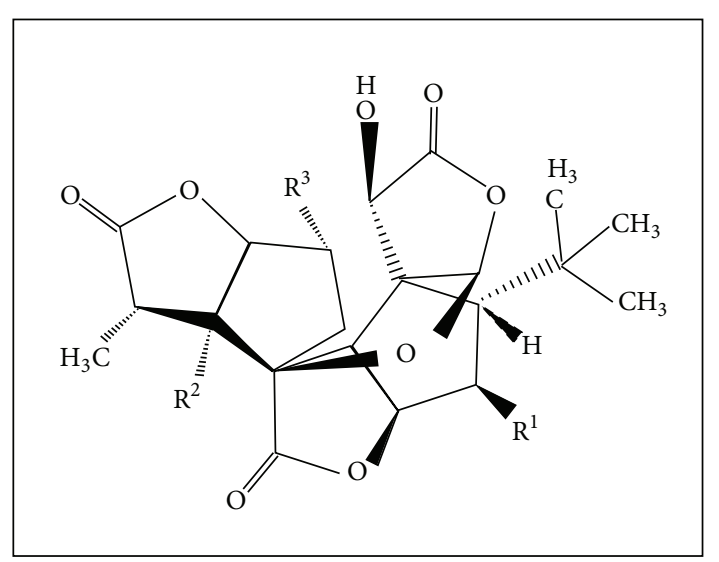

(b)

FIGURE 3: Ginkgo biloba. The plant is classified under the family of Ginkgoaceae, the only species in the division of Ginkgophyta. With $40 \mathrm{~m}$ in height, this tree is characterised by the fan-shaped leaves composed of more than two distinct lobes (a). Ginkgolide $A, R^{1}=H ; R^{2}=H$; $\mathrm{R}^{3}=\mathrm{OH}$, Ginkgolide $\mathrm{B}, \mathrm{R}^{1}=\mathrm{OH} ; \mathrm{R}^{2}=\mathrm{H} ; \mathrm{R}^{3}=\mathrm{OH}$, Ginkgolide $\mathrm{C}, \mathrm{R}^{1}=\mathrm{OH} ; \mathrm{R}^{2}=\mathrm{OH} ; \mathrm{R}^{3}=\mathrm{OH}$, Ginkgolide J, $\mathrm{R}^{1}=\mathrm{H} ; \mathrm{R}^{2}=\mathrm{OH} ; \mathrm{R}^{3}=\mathrm{OH}, \mathrm{Ginkgolide}$ $\mathrm{M}, \mathrm{R}^{1}=\mathrm{OH} ; \mathrm{R}^{2}=\mathrm{OH} ; \mathrm{R}^{3}=\mathrm{H}$ (b) [129].

report has suggested the effect of Ginkgo biloba in treating Alzheimer's disease patient or other cognitive disoders. Ginkgo biloba also has been listed under group of antidementia drugs [128]. It acts as antioxidant and antiapoptotic properties and also induces inhibition effects against caspase-3 activation and amyloid- $\beta$-aggregation toward Alzheimer's disease.

The extract of the leaves diminishes the amyloid- $\beta$ fibrillogenesis, reduces the apoptosis induced by mitochondria, and downregulates the caspase- 3 activity [51]. This plant also is proposed to have antiamyloidogenic property whereby the plant extract prevents the production of amyloid fibrils [51]. The compound found in Ginkgo biloba, terpenoid, namely, bilobalide and ginkgolide, is observed to be involved in the caspase-3 activation [51]. Nakanishi [125] has proposed the memory enhancing effect of ginkgolides. The ginkgolides are compounds in the plant that terminate the effects of amyloid peptide on LTP (Figure 3).

3.5. Panax ginseng. Panax ginseng (Asian ginseng) is described as the "king herb" and has an important position in the traditional Chinese medicine [130]. A lot of reports are discussing the role of $P$. ginseng especially in improving the cognition function of Alzheimer's disease patients. Antioxidant property in P. ginseng is claimed to suppress Alzheimer's disease-like pathology [131]. The intake of $P$. ginseng in healthy individuals is observed to increase the memory performances [132].

The active constituents of the Panax spp. are ginsenoside saponins, which are divided into Panaxadiol, Panaxatriol, and oleanolic acid groups. The Panaxadiol and Panaxatriol groups are studied to increase the release of neurotransmitters in the brain [133]. Other ginsenosides affect the secretion of corticosterone and uptake of $\mathrm{NE}$, dopamine, serotonin, and GABA [134]. It is suggested that the high ratio of Panaxatriol to Panaxadiol is responsible for the enhancement of memory and cognitive properties [135]. P. quinquefolius (American ginseng) has a lower ratio of Panaxatriol to Panaxadiol as compared to P. ginseng (Asian ginseng) (Figure 4) [136].

3.6. Rhodiola rosea. Rhodiola rosea ( $R$. rosea), known as golden root and Arctic root, is reported to improve cognitive function [138], enhance memory and learning [139], and protect the brain [140]. Belonging to the family of Crassulaceae, this plant is observed to increase the level of 5-HT and NE in the cerebral, prefrontal, and frontal cortex [139]. At the same time, the intake of $R$. rosea causes the upregulation of DA and ACh in the limbic system pathways, responsible for emotional calming [141], as $R$. rosea is acting as antioxidant agent. The study showed that the introduction of $R$. rosea may protect the nervous system against oxidative damage, thus lowering the risk of Alzheimer's disease onset. The treatment of the plant also enhances the learning and memory impairment in Alzheimer's disease [142]. Sharing the same property with Bacopa monnieri and Panax ginseng, R. rosea is considered to be an "adaptogen" that enhances endurance, resistance, and protest against stressful situation [143]. Salidroside, an active component of $R$. rosea, is claimed to have neuroprotective and antioxidative effects (Figure 5) [140].

\section{Conclusion}

The understanding of the mechanisms influenced by the administration of natural nootropics has been expanded tremendously in this past decade. Establishing natural nootropic is challenging as optimum dose has to pass blood brain barrier so that it can stimulate responding mechanism. In the same time, the nootropic is helping the body systems such as blood circulation as well as energy booster. There are a number of mechanisms influenced by the administration of nootropics, such as glutaminergic signalling and amyloid precursor protein, also responsible for neuro-related diseases such as dementia and Alzheimer's disease. Thus, the understanding of the mechanism stimulated by nootropic is 


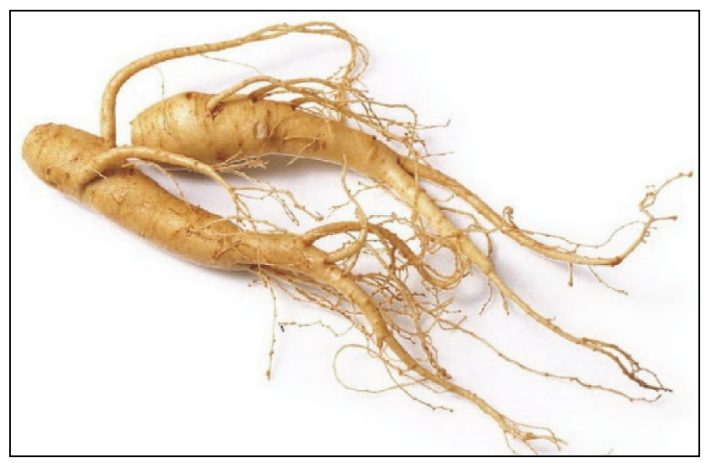

(a)

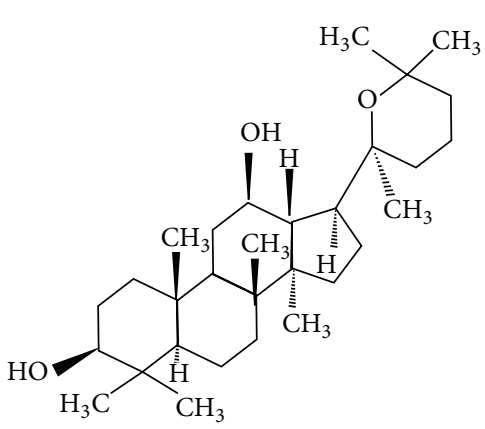

A

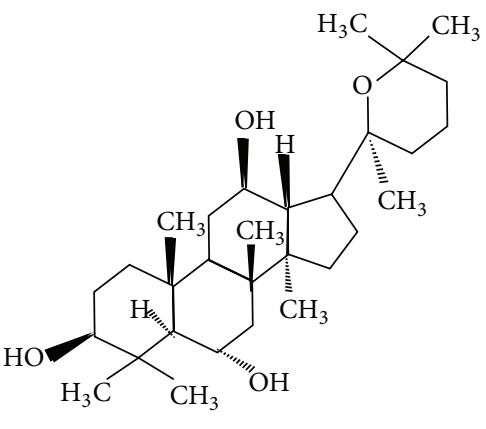

B

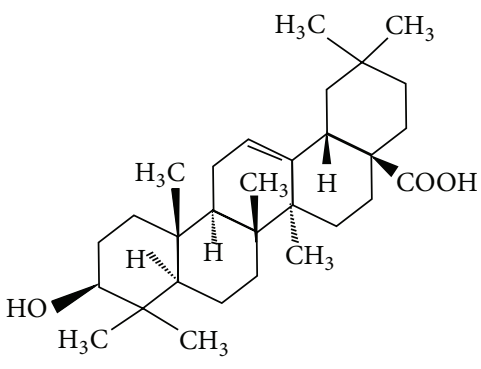

$\mathrm{C}$

(b)

Figure 4: Panax ginseng. Ginseng belongs to the genus Panax of the family Araliaceae, found in the cooler climates. The name of the plant is derived from the Chinese term meaning "person" and "plant root" due to the feature of the root that resembles the legs of a person (a). Ginsenosides, the principal bioactive compounds of P. ginseng. A, Panaxadiol; B, Panaxatriol; C, oleanolic acid (b) [137].

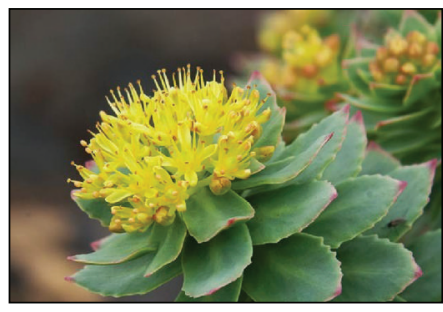

(a)

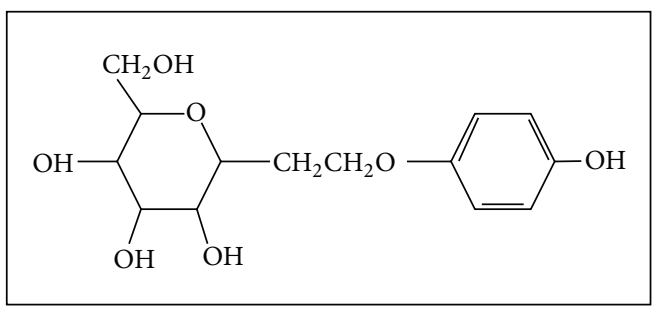

(b)

Figure 5: Rhodiola rosea. It belongs to the family of Crassulaceae. $R$. rosea is growing on the sea cliffs and on the mountains. The plant is dioecious, with yellow to greenish yellow flowers (a). Salidroside is claimed as an active constituent responsible for neuroprotective and antioxidant properties (b) [140].

expected to increase the cognitive performances of the cognitive impairment patients.

\section{Competing Interests}

The authors declare that there is no conflict of interests regarding the publication of this paper.

\section{References}

[1] C. Lanni, S. C. Lenzken, A. Pascale et al., "Cognition enhancers between treating and doping the mind," Pharmacological Research, vol. 57, no. 3, pp. 196-213, 2008.
[2] J.-F. Dartigues, L. Carcaillon, C. Helmer, N. Lechevallier, A. Lafuma, and B. Khoshnood, "Vasodilators and nootropics as predictors of dementia and mortality in the PAQUID cohort," Journal of the American Geriatrics Society, vol. 55, no. 3, pp. 395399, 2007.

[3] J. Kessler, A. Thiel, H. Karbe, and W. D. Heiss, "Piracetam improves activated blood flow and facilitates rehabilitation of poststroke aphasic patients," Stroke, vol. 31, no. 9, pp. 2112-2116, 2000 .

[4] M. E. Raichle and M. A. Mintun, "Brain work and brain imaging," Annual Review of Neuroscience, vol. 29, pp. 449-476, 2006. 
[5] V. Kumar, V. K. Khanna, P. K. Seth, P. N. Singh, and S. K. Bhattacharya, "Brain neurotransmitter receptor binding and nootropic studies on Indian Hypericum perforatum Linn," Phytotherapy Research, vol. 16, no. 3, pp. 210-216, 2002.

[6] P. Radhika, A. Annapurna, and S. N. Rao, "Immunostimulant, cerebroprotective \& nootropic activities of Andrographis paniculata leaves extract in normal \& type 2 diabetic rats," The Indian Journal of Medical Research, vol. 135, no. 5, pp. 636-641, 2012.

[7] K. Melkonyan, "P.1.c.002 influence of nootropil on neuroplasticity of the brain cortex in conditions of hypokinesia," European Neuropsychopharmacology, vol. 16, pp. S224-S225, 2006.

[8] D. S. Garvey, J. T. Wasicak, M. W. Decker et al., "Novel isoxazoles which interact with brain cholinergic channel receptors have intrinsic cognitive enhancing and anxiolytic activities," Journal of Medicinal Chemistry, vol. 37, no. 8, pp. 1055-1059, 1994.

[9] M. Oyaizu and T. Narahashi, "Modulation of the neuronal nicotinic acetylcholine receptor-channel by the nootropic drug nefiracetam," Brain Research, vol. 822, no. 1-2, pp. 72-79, 1999.

[10] M. Marchi, E. Besana, and M. Raiteri, "Oxiracetam increases the release of endogenous glutamate from depolarized rat hippocampal slices," European Journal of Pharmacology, vol. 185, no. 2-3, pp. 247-249, 1990.

[11] J. S. Isaacson and R. A. Nicoll, "Aniracetam reduces glutamate receptor desensitization and slows the decay of fast excitatory synaptic currents in the hippocampus," Proceedings of the National Academy of Sciences of the United States of America, vol. 88, no. 23, pp. 10936-10940, 1991.

[12] J. P. Changeux, A. Klarsfeld, and T. Heidmann, "The acetylcholine receptor and molecular models for short and long term learning," in The Neural and Molecular Bases of Learning, pp. 31-84, John Wiley \& Sons, London, UK, 1987.

[13] M. Amadio, S. Govoni, D. L. Alkon, and A. Pascale, "Emerging targets for the pharmacology of learning and memory," Pharmacological Research, vol. 50, no. 2, pp. 111-122, 2004.

[14] J. Storm-Mathisen, N. C. Danbolt, and O. P. Ottersen, "Localization of glutamate and its membrane transport proteins," in CNS Neurotransmitters and Neuromodulators: Glutamate, pp. 116, CRC Press, New York, NY, USA, 1995.

[15] G. Riedel, B. Platt, and J. Micheau, "Glutamate receptor function in learning and memory," Behavioural Brain Research, vol. 140, no. 1-2, pp. 1-47, 2003.

[16] T. Harkany, I. Ábrahám, W. Timmerman et al., " $\beta$-Amyloid neurotoxicity is mediated by a glutamate-triggered excitotoxic cascade in rat nucleus basalis," European Journal of Neuroscience, vol. 12, no. 8, pp. 2735-2745, 2000.

[17] D. A. Butterfield and C. B. Pocernich, "The glutamatergic system and Alzheimer's disease: therapeutic implications," CNS Drugs, vol. 17, no. 9, pp. 641-652, 2003.

[18] L. S. Dure IV and A. B. Young, "The distribution of glutamate receptor subtypes in mammalian central nervous system using quantitative in vitro autoradiography," in CNS Neurotransmitters and Neuromodulators: Glutamate, pp. 83-94, CRC Press, Boca Raton, Fla, USA, 1995.

[19] D. R. Curtis, J. W. Phillis, and J. C. Watkins, "Chemical excitation of spinal neurones," Nature, vol. 183, no. 4661, pp. 611-612, 1959.

[20] B. Milner, L. R. Squire, and E. R. Kandel, "Cognitive neuroscience and the study of memory," Neuron, vol. 20, no. 3, pp. 445-468, 1998.

[21] T. V. P. Bliss and G. L. Collingridge, "A synaptic model of memory: long-term potentiation in the hippocampus," Nature, vol. 361, no. 6407, pp. 31-39, 1993.
[22] G. Ellison, "The N-methyl-D-aspartate antagonists phencyclidine, ketamine and dizocilpine as both behavioral and anatomical models of the dementias," Brain Research Reviews, vol. 20, no. 2, pp. 250-267, 1995.

[23] J. G. Csernansky, M. Martin, R. Shah, A. Bertchume, J. Colvin, and H. Dong, "Cholinesterase inhibitors ameliorate behavioral deficits induced by MK-801 in mice," Neuropsychopharmacology, vol. 30, no. 12, pp. 2135-2143, 2005.

[24] J. T. Greenamyre, J. B. Penney, C. J. D’Amato, and A. B. Young, "Dementia of the Alzheimer's type: changes in hippocampal L[3H] glutamate binding," Journal of Neurochemistry, vol. 48, no. 2, pp. 543-551, 1987.

[25] J. Ułas, L. C. Brunner, J. W. Geddes, W. Choe, and C. W. Cotman, "N-methyl-D-aspartate receptor complex in the hippocampus of elderly, normal individuals and those with Alzheimer's disease," Neuroscience, vol. 49, no. 1, pp. 45-61, 1992.

[26] M. B. Kennedy, "Regulation of synaptic transmission in the central nervous system: long-term potentiation," Cell, vol. 59, no. 5, pp. 777-787, 1989.

[27] K. Keinanen, W. Wisden, B. Sommer et al., "A family of AMPAselective glutamate receptors," Science, vol. 249, no. 4968, pp. 556-560, 1990.

[28] M. G. Stewart, R. C. Bourne, and R. J. Steele, "Quantitative autoradiographic demonstration of changes in binding to NMDA-sensitive [3H]glutamate and [3H]MK801, but not [3H]AMPA receptors in chick forebrain $30 \mathrm{~min}$ after passive avoidance training," European Journal of Neuroscience, vol. 4, no. 10, pp. 936-943, 1992.

[29] R. E. Hampson, G. Rogers, G. Lynch, and S. A. Deadwyler, "Facilitative effects of the ampakine CX516 on short-term mernory in rats: enhancement of delayed-nonmatch-to-sample performance," The Journal of Neuroscience, vol. 18, no. 7, pp. 2740-2747, 1998.

[30] H. Kaur, D. Singh, B. Singh, and R. K. Goel, "Anti-amnesic effect of Ficus religiosa in scopolamine-induced anterograde and retrograde amnesia," Pharmaceutical Biology, vol. 48, no. 2, pp. 234-240, 2010.

[31] S. Wonnacott, "Presynaptic nicotinic ACh receptors," Trends in Neurosciences, vol. 20, no. 2, pp. 92-98, 1997.

[32] T. Nishizaki, T. Matsuoka, T. Nomura et al., "Nefiracetam modulates acetylcholine receptor currents via two different signal transduction pathways," Molecular Pharmacology, vol. 53, no. 1, pp. 1-5, 1998.

[33] T. Nishizaki, T. Matsuoka, T. Nomura et al., "A 'long-termpotentiation-like' facilitation of hippocampal synaptic transmission induced by the nootropic nefiracetam," Brain Research, vol. 826, no. 2, pp. 281-288, 1999.

[34] C. Ghosh, R. M. Dick, and S. F. Ali, "Iron/ascorbate-induced lipid peroxidation changes membrane fluidity and muscarinic cholinergic receptor binding in rat frontal cortex," Neurochemistry International, vol. 23, no. 5, pp. 479-484, 1993.

[35] W. E. Müller, S. Koch, K. Scheuer, A. Rostock, and R. Bartsch, "Effects of piracetam on membrane fluidity in the aged mouse, rat, and human brain," Biochemical Pharmacology, vol. 53, no. 2, pp. 135-140, 1997.

[36] S. K. Bhattacharya, S. N. Upadhyay, and A. K. Jaiswal, "Effect of piracetam on electroshock induced amnesia and decrease in brain acetylcholine in rats," Indian Journal of Experimental Biology, vol. 31, no. 10, pp. 822-824, 1993.

[37] S. K. Bhattacharya, A. Bhattacharya, A. Kumar, and S. Ghosal, "Antioxidant activity of Bacopa monniera in rat frontal cortex, 
striatum and hippocampus," Phytotherapy Research, vol. 14, no. 3, pp. 174-179, 2000.

[38] S. J. Sara, "Noradrenergic-cholinergic interaction: its possible role in memory dysfunction associated with senile dementia," Archives of Gerontology and Geriatrics, vol. 8, no. 1, pp. 99-108, 1989.

[39] H. K. Singh and B. N. Dhawan, "Neuropsychopharmacological effects of the Ayurvedic nootropic Bacopa monniera Linn. (Brahmi)," Indian Journal of Pharmacology, vol. 29, no. 5, pp. 359-365, 1997.

[40] M. M. Esiri and G. K. Wilcock, "The olfactory bulbs in Alzheimer's disease," Journal of Neurology Neurosurgery and Psychiatry, vol. 47, no. 1, pp. 56-60, 1984.

[41] E. Kirazov, L. Kirazov, V. Bigl, and R. Schliebs, "Ontogenetic changes in protein level of amyloid precursor protein (APP) in growth cones and synaptosomes from rat brain and prenatal expression pattern of APP mRNA isoforms in developing rat embryo," International Journal of Developmental Neuroscience, vol. 19, no. 3, pp. 287-296, 2001.

[42] A. Ishida, K. Furukawa, J. N. Keller, and M. P. Mattson, "Secreted form of $\beta$-amyloid precursor protein shifts the frequency dependency for induction of LTD, and enhances LTP in hippocampal slices," NeuroReport, vol. 8, no. 9-10, pp. 2133-2137, 1997.

[43] G. Huber, Y. Bailly, J. R. Martin, J. Mariani, and B. Brugg, "Synaptic $\beta$-amyloid precursor proteins increase with learning capacity in rats," Neuroscience, vol. 80, no. 2, pp. 313-320, 1997.

[44] P. R. Turner, K. O'Connor, W. P. Tate, and W. C. Abraham, "Roles of amyloid precursor protein and its fragments in regulating neural activity, plasticity and memory," Progress in Neurobiology, vol. 70, no. 1, pp. 1-32, 2003.

[45] S. S. Sisodia, "Alzheimer's disease: perspectives for the new millennium," The Journal of Clinical Investigation, vol. 104, no. 9, pp. 1169-1170, 1999.

[46] J. Cleary, J. M. Hittner, M. Semotuk, P. Mantyh, and E. O'Hare, "Beta-amyloid(1-40) effects on behavior and memory," Brain Research, vol. 682, no. 1-2, pp. 69-74, 1995.

[47] F. Kamenetz, T. Tomita, H. Hsieh et al., "APP processing and synaptic function," Neuron, vol. 37, no. 6, pp. 925-937, 2003.

[48] C. Stadelmann, T. L. Deckwerth, A. Srinivasan et al., "Activation of caspase-3 in single neurons and autophagic granules of granulovacuolar degeneration in Alzheimer's disease: evidence for apoptotic cell death," The American Journal of Pathology, vol. 155, no. 5, pp. 1459-1466, 1999.

[49] J. Marx, "New leads on the 'how' of Alzheimer's," Science, vol. 293, no. 5538, pp. 2192-2194, 2001.

[50] B. A. Yankner, "Mechanisms of neuronal degeneration in Alzheimer's disease," Neuron, vol. 16, no. 5, pp. 921-932, 1996.

[51] Y. Luo, J. V. Smith, V. Paramasivam et al., "Inhibition of amyloid$\beta$ aggregation and caspase- 3 activation by the Ginkgo biloba extract EGb761," Proceedings of the National Academy of Sciences of the United States of America, vol. 99, no. 19, pp. 12197-12202, 2002.

[52] N. Arispe, H. B. Pollard, and E. Rojas, "Giant multilevel cation channels formed by Alzheimer disease amyloid $\beta$ protein $[\mathrm{A} \beta \mathrm{P}-(1-40)]$ in bilayer membranes," Proceedings of the National Academy of Sciences of the United States of America, vol. 90, no. 22, pp. 10573-10577, 1993.

[53] K. L. Sanderson, L. Butler, and V. M. Ingram, "Aggregates of a $\beta$-amyloid peptide are required to induce calcium currents in neuron-like human teratocarcinoma cells: relation to
Alzheimer's disease," Brain Research, vol. 744, no. 1, pp. 7-14, 1997.

[54] J. H. Schwartz, "Cognitive kinases," Proceedings of the National Academy of Sciences of the United States of America, vol. 90, no. 18, pp. 8310-8313, 1993.

[55] J. Pláteník, N. Kuramoto, and Y. Yoneda, "Molecular mechanisms associated with long-term consolidation of the NMDA signals," Life Sciences, vol. 67, no. 4, pp. 335-364, 2000.

[56] A. Routtenberg, "Chapter 18 Synaptic plasticity and protein kinase C," Progress in Brain Research, vol. 69, pp. 211-234, 1986.

[57] J. L. Merrer and X. Noguès, "Cognitive neuropharmacology: new perspectives for the pharmacology of cognition," Pharmacological Research, vol. 41, no. 5, pp. 503-514, 2000.

[58] X. Noguès, R. Jaffard, and J. Micheau, "Investigations on the role of hippocampal protein kinase $\mathrm{C}$ on memory processes: pharmacological approach," Behavioural Brain Research, vol. 75, no. 1-2, pp. 139-146, 1996.

[59] F. Battaini, "Protein kinase C isoforms as therapeutic targets in nervous system disease states," Pharmacological Research, vol. 44, no. 5, pp. 353-361, 2001.

[60] D. Mochly-Rosen and A. S. Gordon, "Anchoring proteins for protein kinase C: a means for isozyme selectivity," The FASEB Journal, vol. 12, no. 1, pp. 35-42, 1998.

[61] F. Battaini, A. Pascale, L. Lucchi, G. M. Pasinetti, and S. Govoni, "Protein kinase $\mathrm{C}$ anchoring deficit in postmortem brains of Alzheimer's disease patients," Experimental Neurology, vol. 159, no. 2, pp. 559-564, 1999.

[62] S. Moriguchi, F. Han, N. Shioda et al., "Nefiracetam activation of CaM kinase II and protein kinase $\mathrm{C}$ mediated by NMDA and metabotropic glutamate receptors in olfactory bulbectomized mice," Journal of Neurochemistry, vol. 110, no. 1, pp. 170-181, 2009.

[63] I. Torres-Aleman, "Serum growth factors and neuroprotective surveillance: focus on IGF-I," Molecular Neurobiology, vol. 21, no. 3, pp. 153-160, 2000.

[64] R. J. Schulingkamp, T. C. Pagano, D. Hung, and R. B. Raffa, "Insulin receptors and insulin action in the brain: review and clinical implications," Neuroscience and Biobehavioral Reviews, vol. 24, no. 8, pp. 855-872, 2000.

[65] C. R. Park, "Cognitive effects of insulin in the central nervous system," Neuroscience and Biobehavioral Reviews, vol. 25, no. 4, pp. 311-323, 2001.

[66] M. W. Schwartz, D. P. Figlewicz, D. G. Baskin, S. C. Woods, and D. Porte Jr., "Insulin in the brain: a hormonal regulator of energy balance," Endocrine Reviews, vol. 13, no. 3, pp. 387-414, 1992.

[67] D. O’Malley, L. J. Shanley, and J. Harvey, "Insulin inhibits rat hippocampal neurones via activation of ATP-sensitive $\mathrm{K}^{+}$and large conductance $\mathrm{Ca}^{2+}$-activated $\mathrm{K}^{+}$channels," Neuropharmacology, vol. 44, no. 7, pp. 855-863, 2003.

[68] G.-J. Biessels, A. Kamal, I. J. A. Urban, B. M. Spruijt, D. W. Erkelens, and W. H. Gispen, "Water maze learning and hippocampal synaptic plasticity in streptozotocin-diabetic rats: effects of insulin treatment," Brain Research, vol. 800, no. 1, pp. 125-135, 1998.

[69] F. Fyhrquist, K. Metsärinne, and I. Tikkanen, "Role of angiotensin II in blood pressure regulation and in the pathophysiology of cardiovascular disorders," Journal of Human Hypertension, vol. 9, no. 5, pp. S19-S24, 1995.

[70] M. I. Phillips, "Functions of angiotensin in the central nervous system," Annual Review of Physiology, vol. 49, pp. 413-435, 1987. 
[71] P. R. Gard, "The role of angiotensin II in cognition and behaviour," European Journal of Pharmacology, vol. 438, no. 12, pp. 1-14, 2002.

[72] J. M. Barnes, N. M. Barnes, B. Costall et al., "Angiotensin II inhibits cortical cholinergic function: implications for cognition," Journal of Cardiovascular Pharmacology, vol. 16, no. 2, pp. 234-238, 1990.

[73] F. J. van der Staay, K. Rutten, C. Erb, and A. Blokland, "Effects of the cognition impairer MK-801 on learning and memory in mice and rats," Behavioural Brain Research, vol. 220, no. 1, pp. 215-229, 2011.

[74] D. L. Priebbenow and C. Bolm, "The rhodium-catalysed synthesis of pyrrolidinone-substituted (trialkylsilyloxy)acrylic esters," RSC Advances, vol. 3, no. 26, pp. 10318-10322, 2013.

[75] U. Schindler, "Pre-clinical evaluation of cognition enhancing drugs," Progress in Neuropsychopharmacology and Biological Psychiatry, vol. 13, no. 1, pp. S99-S115, 1989.

[76] T. Nakajima, M. Takahashi, and T. Okada, "Pharmacological study of aniracetam (VI). Effects of aniracetam on muscarinic acetylcholine receptors in the rat hippocampus," Japanese Pharmacology and Therapeutics, vol. 14, no. 4, pp. 85-91, 1986.

[77] H. Pilch and W. E. Müller, "Piracetam elevates muscarinic cholinergic receptor density in the frontal cortex of aged but not of young mice," Psychopharmacology, vol. 94, no. 1, pp. 74-78, 1988.

[78] K. Winnicka, M. Tomasiak, and A. Bielawska, "Piracetaman old drug with novel properties?" Acta Poloniae PharmaceuticaDrug Research, vol. 62, no. 5, pp. 405-409, 2005.

[79] O. Benešová, "Neuropathobiology of senile dementia and mechanism of action of nootropic drugs," Drugs and Aging, vol. 4, no. 4, pp. 285-303, 1994.

[80] S. Noble and P. Benfield, "Piracetam: a review of its clinical potential in the management of patients with stroke," CNS Drugs, vol. 9, no. 6, pp. 497-511, 1998.

[81] A. H. Gouliaev and A. Senning, "Piracetam and other structurally related nootropics," Brain Research Reviews, vol. 19, no. 2, pp. 180-222, 1994.

[82] B. Winblad, "Piracetam: a review of pharmacological properties and clinical uses," CNS Drug Reviews, vol. 11, no. 2, pp. 169-182, 2005.

[83] Y. Rao, P. Xiao, and S.-T. Xu, "Effects of intrahippocampal aniracetam treatment on Y-maze avoidance learning performance and behavioral long-term potentiation in dentate gyrus in rat," Neuroscience Letters, vol. 298, no. 3, pp. 183-186, 2001.

[84] M. G. Giovannini, P. Rodinò, D. Mutolo, and G. Pepeu, "Oxiracetam and aniracetam increase acetylcholine release from the rat hippocampus in vivo," Drug Development Research, vol. 28, no. 4, pp. 503-509, 1993.

[85] M. Pizzi, C. Fallacara, V. Arrighi, M. Memo, and P. Spano, "Attenuation of excitatory amino acid toxicity by metabotropic glutamate receptor agonists and aniracetam in primary cultures of cerebellar granule cells," Journal of Neurochemistry, vol. 61, no. 2, pp. 683-689, 1993.

[86] J. R. Martin and W. E. Haefely, "Pharmacology of aniracetam," Drug Investigation, vol. 5, no. 1, pp. 4-49, 1993.

[87] E. Schwam, K. Keim, R. Cumin, E. Gamzu, and J. Sepinwall, "Effects of aniracetam on primate behavior and EEG," Annals of the New York Academy of Sciences, vol. 444, no. 1, pp. 482-484, 1985.

[88] J. J. Lawrence, S. Brenowitz, and L. O. Trussell, "The mechanism of action of aniracetam at synaptic $\alpha$-amino-3-hydroxy-5methyl-4-isoxazolepropionic acid (AMPA) receptors: indirect and direct effects on desensitization," Molecular Pharmacology, vol. 64, no. 2, pp. 269-278, 2003.

[89] Y. Sun, R. Olson, M. Horning, N. Armstrong, M. Mayer, and E. Gouaux, "Mechanism of glutamate receptor desensitization," Nature, vol. 417, no. 6886, pp. 245-253, 2002.

[90] Y. Lu and J. M. Wehner, "Enhancement of contextual fearconditioning by putative $( \pm)$ - $\alpha$-amino-3-hydroxy-5-methylisoxazole-4-propionic acid (AMPA) receptor modulators and $\mathrm{N}$-methyl-D-aspartate (NMDA) receptor antagonists in DBA/ 2J mice," Brain Research, vol. 768, no. 1-2, pp. 197-207, 1997.

[91] A. R. Gomes, S. S. Correia, A. L. Carvalho, and C. B. Duarte, "Regulation of AMPA receptor activity, synaptic targeting and recycling: role in synaptic plasticity," Neurochemical Research, vol. 28, no. 10, pp. 1459-1473, 2003.

[92] T. Sakurai, H. Ojima, T. Yamasaki, H. Kojima, and A. Akashi, "Effects of N-(2,6-dimethylphenyl)-2-(2-oxo-1-pyrrolidinyl) acetamide (DM-9384) on learning and memory in rats," The Japanese Journal of Pharmacology, vol. 50, no. 1, pp. 47-53, 1989.

[93] T. Nabeshima, "Ameliorating effects of Nefiracetam (DM-9384) on brain dysfunction," Drugs of Today, vol. 30, no. 5, pp. 357379, 1994.

[94] D. S. Woodruff-Pak, "Nefiracetam ameliorates learning deficits in older rabbits and may act via the hippocampus," Behavioural Brain Research, vol. 83, no. 1-2, pp. 179-184, 1997.

[95] Y. L. Murashima, T. Shinozaki, S. Watabe, and M. Yoshii, "Enhancements of cAMP by low concentrations of enkephalin and the nootropic nefiracetam (DM-9384) in NG108-15," Neuroscience Research Supplements, vol. 19, article S102, 1994.

[96] C. Ghelardini, N. Galeotti, F. Gualtieri et al., "DM235 (sunifiram): a novel nootropic with potential as a cognitive enhancer," Naunyn-Schmiedeberg's Archives of Pharmacology, vol. 365, no. 6, pp. 419-426, 2002.

[97] R. Verloes, A.-M. Scotto, J. Gobert, and E. Wülfert, "Effects of nootropic drugs in a scopolamine-induced amnesia model in mice," Psychopharmacology, vol. 95, no. 2, pp. 226-230, 1988.

[98] S. M. DeFord, M. S. Wilson, C. J. Gibson, A. Baranova, and R. J. Hamm, "Nefiracetam improves Morris water maze performance following traumatic brain injury in rats," Pharmacology Biochemistry and Behavior, vol. 69, no. 3-4, pp. 611-616, 2001.

[99] D. Manetti, C. Ghelardini, A. Bartolini et al., "Design, synthesis, and preliminary pharmacological evaluation of 1,4diazabicyclo[4.3.0]nonan-9-ones as a new class of highly potent nootropic agents," Journal of Medicinal Chemistry, vol. 43, no. 10, pp. 1969-1974, 2000.

[100] D. Jersalinsky, J. A. Quillfeldt, R. Walz et al., "Effect of the infusion of the GABA-A receptor agonist, muscimol, on the role of the entorhinal cortex, amygdala, and hippocampus in memory processes," Behavioral and Neural Biology, vol. 61, no. 2, pp. 132-138, 1994.

[101] S. Moriguchi, T. Tanaka, T. Narahashi, and K. Fukunaga, "Novel nootropic drug sunifiram enhances hippocampal synaptic efficacy via glycine-binding site of N-methyl-D-aspartate receptor," Hippocampus, vol. 23, no. 10, pp. 942-951, 2013.

[102] K. A. Wafford, M. Kathoria, C. J. Bain et al., "Identification of amino acids in the N-methyl-D-aspartate receptor NR1 subunit that contribute to the glycine binding site," Molecular Pharmacology, vol. 47, no. 2, pp. 374-380, 1995.

[103] S. Moriguchi, T. Tanaka, H. Tagashira, T. Narahashi, and K. Fukunaga, "Novel nootropic drug sunifiram improves cognitive deficits via CaM kinase II and protein kinase C activation in olfactory bulbectomized mice," Behavioural Brain Research, vol. 242, no. 1, pp. 150-157, 2013. 
[104] G. V. Satyavati, M. K. Raina, and M. Sharma, Indian Medicinal Plants, Indian Council of Medical Research, New Delhi, India, 1976.

[105] S. Roodenrys, D. Booth, S. Bulzomi, A. Phipps, C. Micallef, and J. Smoker, "Chronic effects of Brahmi (Bacopa monnieri) on human memory," Neuropsychopharmacology, vol. 27, no. 2, pp. 279-281, 2002.

[106] N. Chatterji, R. P. Rastogi, and M. L. Dhar, "Chemical examination of Bacopa monniera Wettst.: Part I-Isolation of chemical constituents," 1963.

[107] H. Singh and B. N. Dhawan, "Drugs affecting learning and memory," flJ, 189, 1992.

[108] H. K. Singh, R. P. Rastogi, R. C. Srimal, and B. N. Dhawan, "Effect of bacosides A and B on avoidance responses in rats," Phytotherapy Research, vol. 2, no. 2, pp. 70-75, 1988.

[109] A. Russo and F. Borrelli, "Bacopa monniera, a reputed nootropic plant: an overview," Phytomedicine, vol. 12, no. 4, pp. 305-317, 2005.

[110] H. K. Singh, R. C. Srimal, A. K. Srivastava, N. K. Garg, and B. N. Dhawan, "Neuropsycho pharmacological effects of bacosides A and B," in Proceedings of 4th Conference on the Neurobiology of Learning and Memory, pp. 17-20, October 1990.

[111] T. Anand, M. Naika, M. S. L. Swamy, and F. Khanum, "Antioxidant and DNA damage preventive properties of Bacopa monniera (L) wettst," Free Radicals and Antioxidants, vol. 1, no. 1, pp. 84-90, 2011.

[112] T. Sumathy, S. Subramanian, S. Govindasamy, K. Balakrishna, and G. Veluchamy, "Protective role of Bacopa monniera on morphine induced hepatotoxicity in rats," Phytotherapy Research, vol. 15, no. 7, pp. 643-645, 2001.

[113] A. Dar and S. Channa, "Calcium antagonistic activity of Bacopa monniera on vascular and intestinal smooth muscles of rabbit and guinea-pig," Journal of Ethnopharmacology, vol. 66, no. 2, pp. 167-174, 1999.

[114] V. Elangovan, S. Govindasamy, N. Ramamoorthy, and K. Balasubramanian, "In vitro studies on the anticancer activity of Bacopa monnieri," Fitoterapia, vol. 66, no. 3, pp. 211-215, 1995.

[115] T. Sumathi, K. Balakrishna, G. Veluchamy, and S. Niranjali Devaraj, "Inhibitory effect of Bacopa monniera on morphine induced pharmacological effects in mice," Natural Product Sciences, vol. 13, no. 1, pp. 46-53, 2007.

[116] D. Kar Chowdhuri, D. Parmar, P. Kakkar, R. Shukla, P. K. Seth, and R. C. Srimal, "Antistress effects of bacosides of Bacopa monnieri: modulation of Hsp70 expression, superoxide dismutase and cytochrome P450 activity in rat brain," Phytotherapy Research, vol. 16, no. 7, pp. 639-645, 2002.

[117] T. Sumathi and S. Ramakrishnan, "Hepatoprotective activity of Bacopa monniera on D-galactosamine induced hepatotoxicity in rats," Natural Product Sciences, vol. 13, no. 3, pp. 195-198, 2007.

[118] T. Sumathi and A. Nongbri, "Hepatoprotective effect of Bacoside-A, a major constituent of Bacopa monniera Linn," Phytomedicine, vol. 15, no. 10, pp. 901-905, 2008.

[119] R. L. Metcalf, "Insect control," in Ullmann's Encyclopedia of Industrial Chemistry, 1989.

[120] G. K. Lloyd and M. Williams, "Neuronal nicotinic acetylcholine receptors as novel drug targets," Journal of Pharmacology and Experimental Therapeutics, vol. 292, no. 2, pp. 461-467, 2000.

[121] E. D. Levin, "Nicotinic systems and cognitive function," Psychopharmacology, vol. 108, no. 4, pp. 417-431, 1992.

[122] N. Khurana, M. P. S. Ishar, A. Gajbhiye, and R. K. Goel, "PASS assisted prediction and pharmacological evaluation of novel nicotinic analogs for nootropic activity in mice," European Journal of Pharmacology, vol. 662, no. 1-3, pp. 22-30, 2011.

[123] E. D. Levin, F. J. McClernon, and A. H. Rezvani, "Nicotinic effects on cognitive function: behavioral characterization, pharmacological specification, and anatomic localization," Psychopharmacology, vol. 184, no. 3-4, pp. 523-539, 2006.

[124] S. Kaiser and S. Wonnacott, "Nicotinic receptor modulation of neurotransmitter release," in Neuronal Nicotinic Receptors: Pharmacology and Therapeutic Opportunities, pp. 141-159, John Wiley \& Sons, New York, NY, USA, 1998.

[125] K. Nakanishi, “Terpene trilactones from Gingko biloba: from ancient times to the 21st century," Bioorganic and Medicinal Chemistry, vol. 13, no. 17, pp. 4987-5000, 2005.

[126] A. J. Coombes, Dictionary of Plant Names, Hamlyn Books, London, UK, 1994.

[127] Y. Christen, "Ginkgo biloba and neurodegenerative disorders," Frontiers in Bioscience, vol. 9, no. 1-3, pp. 3091-3104, 2004.

[128] S. Weinmann, S. Roll, C. Schwarzbach, C. Vauth, and S. N. Willich, "Effects of Ginkgo biloba in dementia: systematic review and meta-analysis," BMC geriatrics, vol. 10, article 14, 2010.

[129] N. H. Andersen, N. J. Christensen, P. R. Lassen et al., "Structure and absolute configuration of ginkgolide $\mathrm{B}$ characterized by IRand VCD spectroscopy," Chirality, vol. 22, no. 2, pp. 217-223, 2010.

[130] J.-T. Xie, S. Mehendale, and C.-S. Yuan, "Ginseng and diabetes," The American Journal of Chinese Medicine, vol. 33, no. 3, pp. 397404, 2005.

[131] L. L. D. Santos-Neto, M. A. De Vilhena Toledo, P. MedeirosSouza, and G. A. De Souza, "The use of herbal medicine in Alzheimer's disease-a systematic review," Evidence-Based Complementary and Alternative Medicine, vol. 3, no. 4, pp. 441445, 2006.

[132] D. O. Kennedy and A. B. Scholey, "Ginseng: potential for the enhancement of cognitive performance and mood," Pharmacology Biochemistry and Behavior, vol. 75, no. 3, pp. 687-700, 2003.

[133] J.-T. Zhang, Z.-W. Qu, Y. Liu, and H.-L. Deng, "Preliminary study on the antiamnestic mechanism of ginsenoside Rg1 and Rb1," European Journal of Pharmacology, vol. 183, no. 4, pp. 1460-1461, 1990.

[134] D. Tsang, H. W. Yeung, W. W. Tso, and H. Peck, "Ginseng saponins: influence on neurotransmitter uptake in rat brain synaptosomes," Planta Medica, vol. 3, pp. 221-224, 1985.

[135] S.-H. Jin, J.-K. Park, K.-Y. Nam, S.-N. Park, and N.-P. Jung, "Korean red ginseng saponins with low ratios of protopanaxadiol and protopanaxatriol saponin improve scopolamineinduced learning disability and spatial working memory in mice," Journal of Ethnopharmacology, vol. 66, no. 2, pp. 123-129, 1999.

[136] W. Li and J. F. Fitzloff, "HPLC determination of ginsenosides content in ginseng dietary supplements using ultraviolet detection," Journal of Liquid Chromatography and Related Technologies, vol. 25, no. 16, pp. 2485-2500, 2002.

[137] H. N. Murthy, M. I. Georgiev, Y.-S. Kim et al., "Ginsenosides: prospective for sustainable biotechnological production," Applied Microbiology and Biotechnology, vol. 98, no. 14, pp. 6243-6254, 2014.

[138] A. A. Spasov, G. K. Wikman, V. B. Mandrikov, I. A. Mironova, and V. V. Neumoin, "A double-blind, placebo-controlled pilot study of the stimulating and adaptogenic effect of Rhodiola rosea SHR-5 extract on the fatigue of students caused by stress 
during an examination period with a repeated low-dose regimen," Phytomedicine, vol. 7, no. 2, pp. 85-89, 2000.

[139] M. B. Lazarova, V. D. Petkov, V. L. Markovska, and A. Mosharrof, "Effects of meclofenoxate and Extr. Rhodiolae roseae L. on electroconvulsive shock-impaired learning and memory in rats," Methods and Findings in Experimental and Clinical Pharmacology, vol. 8, no. 9, pp. 547-552, 1986.

[140] X. Chen, J. Liu, X. Gu, and F. Ding, "Salidroside attenuates glutamate-induced apoptotic cell death in primary cultured hippocampal neurons of rats," Brain Research, vol. 1238, pp. 189198, 2008.

[141] M. Furmanowa, E. Skopińska-Rozewska, E. Rogala, and M. Hartwich, "Rhodiola rosea in vitro culture-phytochemical analysis and antioxidant action," Acta Societatis Botanicorum Poloniae, vol. 67, no. 1, pp. 69-73, 2014.

[142] Z.-Q. Qu, Y. Zhou, Y.-S. Zeng, Y. Li, and P. Chung, "Pretreatment with rhodiola rosea extract reduces cognitive impairment induced by intracerebroventricular streptozotocin in rats: implication of anti-oxidative and neuroprotective effects," Biomedical and Environmental Sciences, vol. 22, no. 4, pp. 318326, 2009.

[143] I. I. Brekhman and I. V. Dardymov, "New substances of plant origin which increase nonspecific resistance," Annual Review of Pharmacology, vol. 9, no. 1, pp. 419-430, 1969. 


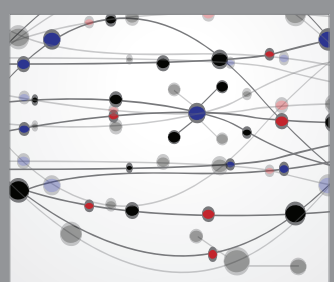

The Scientific World Journal
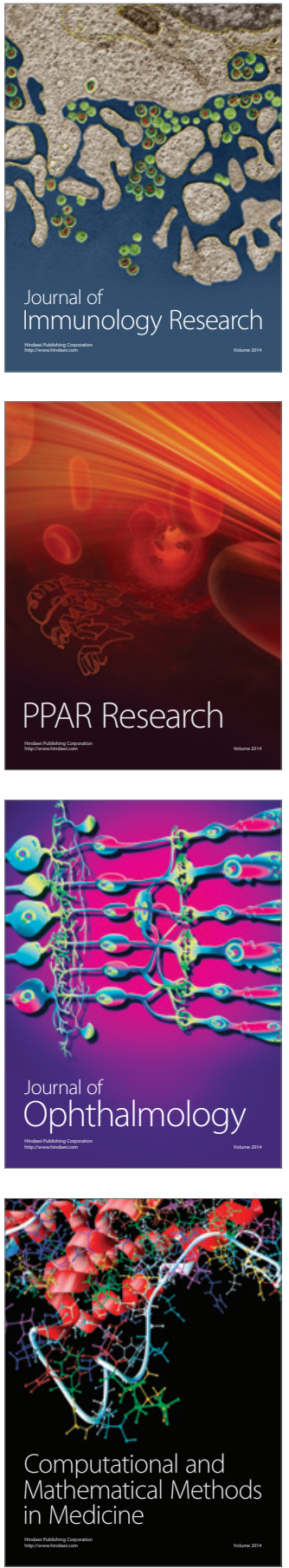

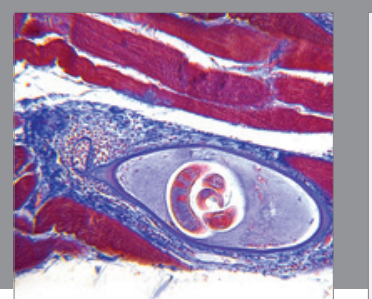

Gastroenterology Research and Practice

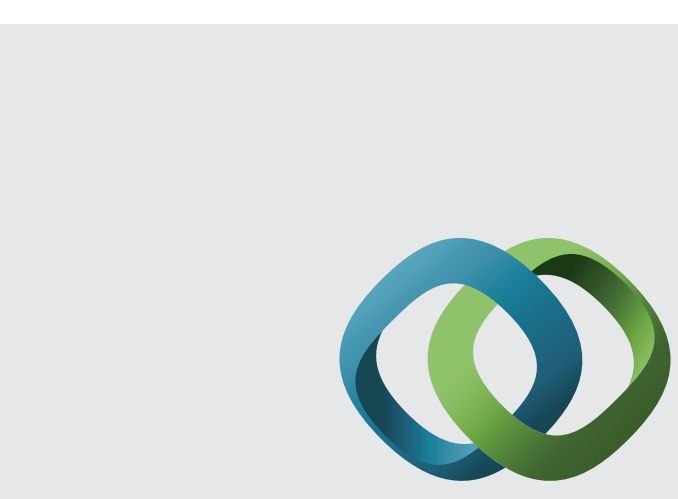

\section{Hindawi}

Submit your manuscripts at

http://www.hindawi.com
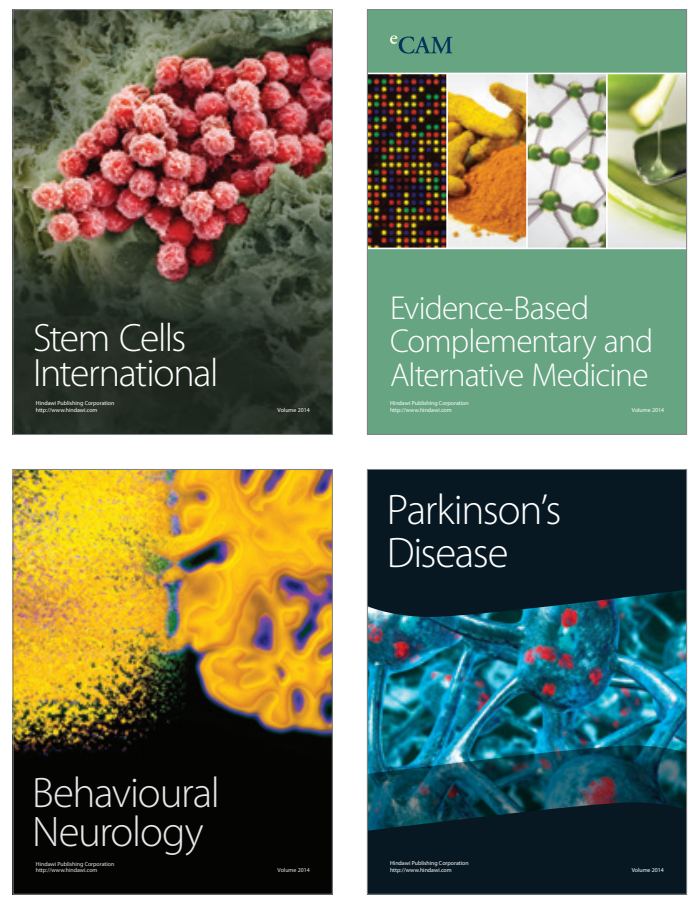
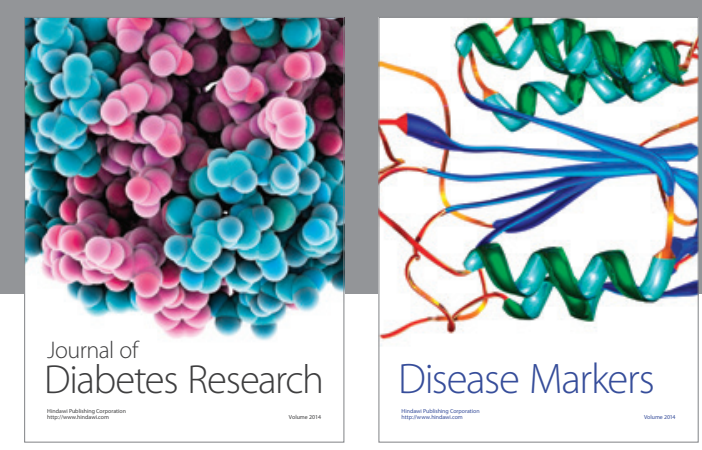

Disease Markers
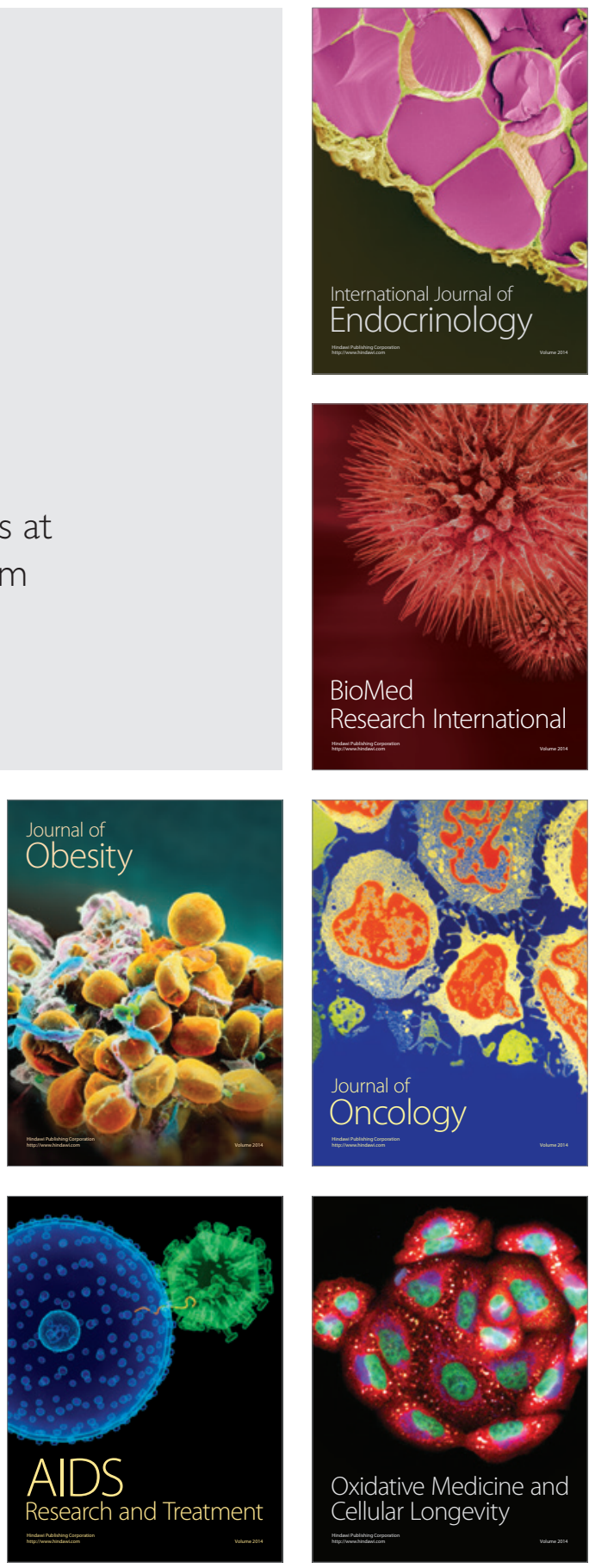